\title{
THE STRATEGY TO SUPPORT HTGR FUELS FOR THE 10 MW INDONESIA'S EXPERIMENTAL POWER \\ REACTOR (RDE)
}

\author{
Taswanda Taryo ${ }^{1}$, Ridwan $^{2}$, Geni Rina Sunaryo ${ }^{1}$, Meniek Rachmawati ${ }^{2}$ \\ ${ }^{1}$ Center for Reactor Technology and Nuclear Safety - BATAN \\ Kawasan Puspiptek Serpong Gd.80, Tangerang Selatan, Banten 15314 \\ ${ }^{2}$ Center for Fuel Element Technology - BATAN, \\ Kawasan Puspiptek Serpong Gd.20, Tangerang Selatan, Banten 15314 \\ Email: taryo@batan.go.id
}

(Naskah diterima: 21-12-2017, Naskah direvisi: 29-12-2017, Naskah disetujui: 27-01-2018)

\begin{abstract}
STRATEGY TO SUPPORT HTGR FUEL FOR THE 10 MW INDONESIA'S EXPERIMENTAL POWER REACTOR (RDE). The Indonesia's $10 \mathrm{MW}$ experimental power reactor (RDE) is developed based on high temperature gas-cooled reactor (HTGR) and the program of the RDE was firstly introduced to the Agency for National Development Planning (BAPPENAS) at the beginning of 2014. The RDE program is expected to have positive impacts on community prosperity, self-reliance and sovereignty of Indonesia. The availability of RDE will be able to accelerate advanced nuclear power technology development and hence elevate Indonesia to be the nuclear champion in the ASEAN region. The RDE is expected to be operable in 2022/2023. In terms of fuel supply for the reactor, the first batch of RDE fuel will be inclusive in the RDE engineering, procurement and construction (RDE-EPC) contract for the assurance of the RDE reactor operation from 2023 to 2027 . Consideration of RDE fuel plant construction is important as RDE can be the basis for the development of reactors of similar type with small-medium power (25 MWe-200/300 MWe), which are preferable for eastern part of Indonesia. To study the feasibility of the construction of RDE fuel plant, current state of the art of the R\&D on HTGR fuel in some advanced countries such as European countries, the United States, South Africa and Japan will be discussed and overviewed to draw a conclusion about the prospective countries for supporting the fuel for long-term RDE operation. The strategy and roadmap for the preparation of the RDE fuel plant construction with the involvement of national stakeholders have been developed. The best possible vendor country to support HTGR fuel for long-term operation is finally accomplished. In the end, this paper can be assigned as a reference for the planning and construction of HTGR RDE fuel fabrication plant in Indonesia.
\end{abstract}

Keywords: RDE, Indonesia, HTGR, fuel, strategy. 


\section{ABSTRAK}

STRATEGI UNTUK MENDUKUNG BAHAN BAKAR REAKTOR DAYA EKSPERIMENTAL (RDE). Reaktor Daya Eksperimental (RDE) 10 MW berbasis pada High Temperature Gas-Cooled Reactor (HTGR) dan program Reaktor Daya Eksperimental 10 MW (RDE) pertama kali disampaikan ke Badan Perencanaan Pembangunan Nasional (BAPPENAS) tahun 2014. Program RDE sangat diharapkan memberikan dampak positip dalam menjadikan masyarakat Indonesia sejahtera, mandiri dan berdaulat. Pembangunan RDE dapat mempercepat penguasaan teknologi canggih nuklir maju sehingga Indonesia menjadi kampiun di regional ASEAN dan RDE diharapkan beroperasi tahun 2022/2023. Berkaitan dengan pemakaian bahan bakar tahap pertama untuk RDE, kebutuhan bahan bakar akan dimasukkan dalam kontrak pembangunan RDE sehingga operasi RDE dijamin sejak pertama beroperasi tahun 2023 sampai 2027. Membangun pabrik bahan bakar RDE merupakan hal penting yang perlu dipertimbangkan mengingat RDE menjadi dasar untuk mengembangkan reaktor sejenis dan berdaya kecilmenengah (25 MWe-200/300 MWe) yang dapat dibangun di Indonesia bagian Timur. Untuk mengkaji kemungkinan pembangunan pabrik bahan bakar RDE, pertama, perkembangan litbang bahan bakar HTGR oleh negara maju, seperti, negara-negara Eropa, Amerika Serikat, Afrika Selatan, Jepang dan dibahas sehingga dapat disimpulkan negara mana yang dapat mendukung keperluan bahan bakar untuk pengoperasian RDE. Kemudian strategi nasional serta peta jalan dan sasaran untuk persiapan pembangunan pabrik bahan bakar RDE disampaikan secara rinci. Telah disimpulkan, negara vendor terbaik yang dapat mendukung pembangunan pabrik bahan bakar untuk keperluan pengoperasian RDE jangka panjang. Akhirnya, makalah ini dapat dijadikan acuan primer dalam perencanaan dan pembangunan pabrik bahan bakar RDE di Indonesia.

Kata kunci: RDE, Indonesia, HTGR, bahan bakar, strategi. 


\section{INTRODUCTION}

The development of the $10 \mathrm{MW}$ Indonesia's Experimental Power Reactor (RDE) is on-going progress, and the decision to build the RDE is made with consideration of the basic rules and technical reasons are as follows:

The Act number 17 year 2007 regarding the Long Term of National Development Plan (RPJPN 2005-2025) and The Government Decree number 14 Year 2015 on The Master Plan of National Industry Development 2015-2035 (RIPIN 2015-2035) have authorized the application of nuclear energy with very strict safety consideration in 2015-2019 and the use of nuclear-energy-generated industry commencing in 2020. In the Plenary Meeting of the National Energy Chamber (DEN) held on June 22, 2016, Mr. President Joko Widodo suggested the construction of the RDE, in which the reactor can be operated by Indonesia relevant researchers to express, interact, create and support all nuclear research activities in the country and hence all significant results can be preserved to strengthen international collaboration and to always be well informed with the world latest nuclear technology [1].

Based on the Act number 10 Year 1997 and the Government Decree Number 2 Year 2014, the Indonesia National Nuclear Energy Agency (BATAN) has the authority to implement nuclear research activities as well as to construct, operate and commission a non-commercial nuclear reactor in the country.

As the world trend on R\&Ds is of High Temperature Gas-Cooled Reactor (HTGR)[2,3,4], BATAN has decided to develop an HTGR reactor in the country. Not only has the HTGR a very safe performance, but it can also be employed for other purposes, such as water desalination, hydrogen production, coal liquefaction, etc. [3].

The HTGR reactor not only consumes fuel flexibility, but is also a proven technology, competitive in price, and commercially prospective in the near future as some advanced countries (Germany, France, USA, Russia, China, Japan, Republic of Korea, etc.) have performed significant R\&Ds on HTGRs since 1980s [4]. The power of the reactor can also be expanded to support small-medium electric power in the Eastern part of Indonesia in the future as well as to desalinate sea-water to drinking-water[5]. The vision to build RDE-10, as seen in Figure 1, is to enhance Indonesia to become the first nuclear country in the Association of South East Asia Nations (ASEAN) region as a nuclear technology provider to advance HTGR for electricity and cogeneration for industry in the future. The RDE will technically produce 2.9 MWe and only 0.4 MWe will be consumed for internal operation, while the rest will be applied for BATAN internal electric supply as well as for communityneed electricity around the RDE site [5]. The design specification of the RDE is shown in Table 1. The RDE is also keen to intensify public acceptance on nuclear power plant (NPP) and to advance national capacity building not only in implementing nuclear research activities, but also in manufacturing and construction to support the development of nuclear industry in the country. 


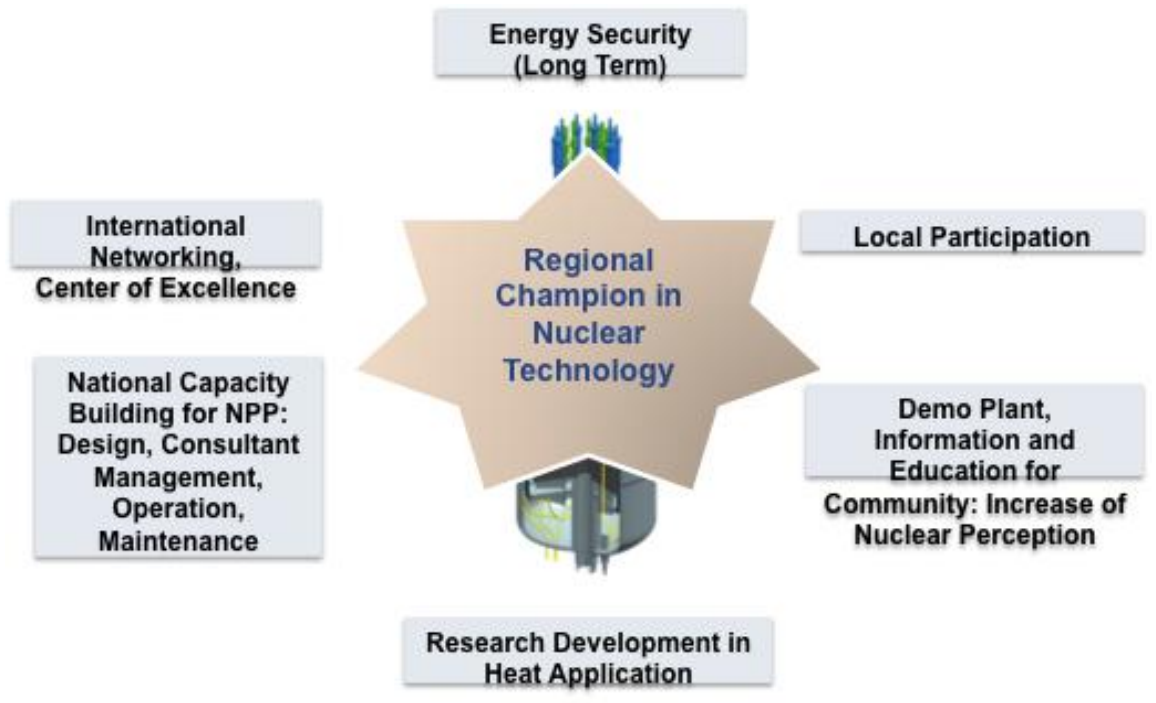

Figure 1. The advantages of RDE [5]

There are two concepts of fuel elements presently exploited for HTGRs, namely, the spherical fuel element used in pebble bed concept in Germany and Russia (now also in China and South Africa) and the block-type fuel element applied in prismatic core in the United States [4], the United Kingdom, Japan and also Russia. Both types of HTGR fuels are presented in Figure 2. The spherical fuel element is a graphitic sphere with a diameter of $60 \mathrm{~mm}$ composed of a fuel zone of $50 \mathrm{~mm}$ in diameter with around 10,000 coated particles. The particles are over-coated with a matrix graphite layer with a thickness of around 200 $\mathrm{mm}$ to prevent direct contact of the particles, which are dispersed uniformly in the same matrix graphite material. The outermost 5 $\mathrm{mm}$ of the fuel sphere is a shell of matrix graphite only without any particles.

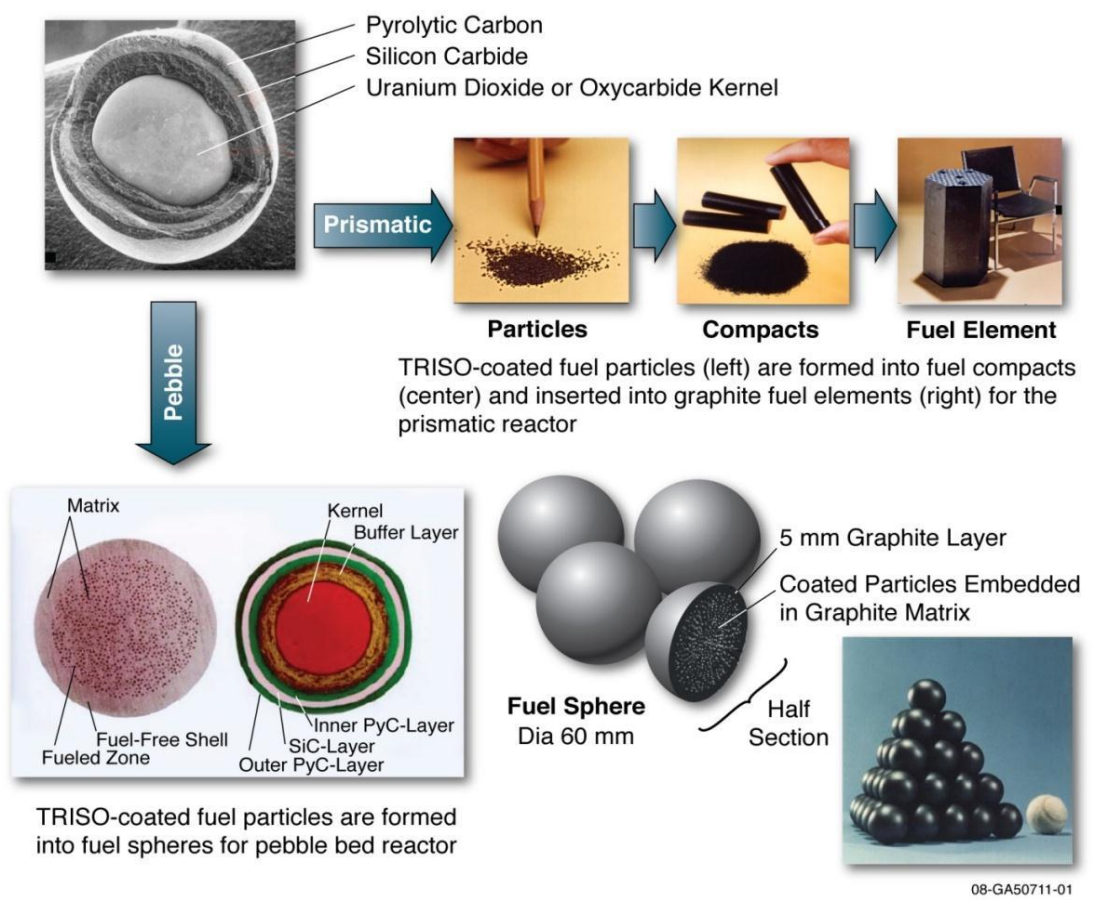

Figure 2. Schematic of coated fuel particle and fuel element for HTGR [6] 
Referring to [4], the block-type fuel element in US design is a hexagonal graphite block $(793 \mathrm{~mm}$ in length and 360 $\mathrm{mm}$ wide across the flat surface) containing 102 coolant channels and 210 fuel holes filled with fuel compacts and sealed. The fuel compacts are a mixture of TRISO-coated fissile and fertile particles and graphite shim particles bonded by a carbonaceous matrix. In addition, the Japanese fuel element design is similar to the previous Dragon Project "pin-in-block" design. Each hexagonal graphite block (580 $\mathrm{mm}$ in length and $360 \mathrm{~mm}$ wide across the flat surface) has 31 or 33 fuel holes, each of which contains an annular fuel pin that consists of 14 fuel compacts in a graphite sleeve. Furthermore, a fuel compact made of graphite matrix powder with the shape of an annular cylinder contains 13,500 TRISO-coated fissile particles.

Based on the plan, the RDE will be operated in 2022/2023, and for one cycle the RDE will need around 27,000 of HTGR ball fuels [5]. Basically, for a certain time, the fuel needed for reactor operation will be inclusive in the same contract called the RDE-EPC contract (engineering, procurement and construction). Up to now, BATAN has safely operated a multipurpose reactor G.A. Siwabessy (RSG-GAS) since 1987, and the fuel fabrication plant has been established to support the need of fuel to operate the RSG-GAS reactor since 1989. BATAN has also operated both the TRIGA 2000 reactor since 1965 in Bandung and the Kartini Reactor since 1979 in Yogyakarta. This paper designates national capabilities on nuclear fuel research to support HTGR fuels for RDE operation. To support the previous matter, R\&Ds on HTGR fuels done by Europe countries, USA, South Africa, Japan and China) are described. The roadmaps for the preparation of RDE fuel manufacturing plant involving in main national stakeholders are developed. The assessment of the best possible vendor countries to support HTGR fuels for RDE operation is also explored.

\section{METHODOLOGY}

One of the aims to develop the RDE is to enlarge the role of national capacity building and that of local industry during the construction of HTGR fuel plant in the country. To begin with the matter, the current status of the RDE development as well as national capabilities in nuclear fuel research, design and engineering is explored. To enhance the national capabilities on nuclear fuel development, a lot of associated R\&Ds and fabrication on HTGR fuels in regions (Europe, Asia Pacific, South Africa and the United States of America) are reviewed and appraised in this paper [2-4, 6, 11-33].

The potential HTGR fuel vendors from the regions are conversed and assessed as well. The strategy to support the short, long term RDE operation is then proposed by developing a road map to support that in the future. The results are then summarized to obtain the best strategy to assure the continuity of the safe RDE operation in Indonesia.

\section{RESULTS AND DISCUSSIONS}

\section{a. Current status of RDE development in Indonesia}

The Ministry of Research Technology and Higher Education and the Ministry of Finance have respectively permitted an RDE site almost 9 ha in Puspiptek Serpong, Tangerang Selatan since 2015 and the RDE site is around 500 meters from the existing $30 \mathrm{MW}$ Multi Purpose Reactor G.A. Siwabessy (RSG-GAS) reactor operated from 1987. The national nuclear regulatory body (BAPETEN) has declared the RDE site permit No. 001/IT/Ka-BAPETEN/23-I/2017 dated on January 23, 2017. In addition, BATAN has been acquiring the RDE basic 
design and the design was completed at the end of September 2017. The RDE components and systems have been drawn in detail and even the price of RDE project has been accurately approximated.

The HTGR has been becoming a world trend not only for the need of electricity, but also for industrial purposes, such as hydrogen production, water desalination, coal liquefaction, etc. Up to more than five decades of HTGR fuel development, the German $\mathrm{UO}_{2}$ and the US low enriched uranium of uranium carbon oxide (LEU-UCO) coated particles represent highly successful coated particle designs up to now [4]. After the Chinese $10 \mathrm{MW}$ high temperature gas-cooled reactor (HTR-10) had its first criticality on December 21, 2000 [9] and the complete construction of the 200 MW Chinese high temperature gas-cooled reactor pebble-bed module (HTR-PM) in the middle of 2015, the development of HTGR fuels has been of major concern of the world trend in the last two decades $[3,4]$.

Table 1. Design specification of RDE [5]

\begin{tabular}{|c|c|c|}
\hline \multicolumn{3}{|l|}{ Basic Data } \\
\hline Reactor power (thermal) & 10 & MW (Thermal) \\
\hline Mean power density & 2.0 & $\mathrm{MW} / \mathrm{m}^{3}$ \\
\hline Core diameter & 1.8 & M \\
\hline Mean core height & 2.0 & M \\
\hline Primary system pressure & 30 & Bar \\
\hline Flow direction & Downwards & \\
\hline Primary coolant temperature (inlet/outlet) & $250 / 700$ & ${ }^{\circ} \mathrm{C}$ \\
\hline Number of fuel elements in core & 27,000 & pieces \\
\hline Enrichment & $17 \%$ & w/o \\
\hline Target burn-up & 80,000 & $\mathrm{MWd} / \mathrm{MgU}$ \\
\hline Mean of fuel element (FE) output & 0.37 & kW/FE \\
\hline \multicolumn{3}{|c|}{$1^{\text {st }}$ and $2^{\text {nd }}$ Shutdown System of RDE } \\
\hline Rods & 10 & Pieces \\
\hline Absorber length & 2,200 & $\mathrm{Mm}$ \\
\hline Absorber diameter & 100 & $\mathrm{Mm}$ \\
\hline Maximum travel & 2,600 & $\mathrm{Mm}$ \\
\hline Normal speed & 1 & $\mathrm{~cm} / \mathrm{s}$ \\
\hline Absorber material & $\mathrm{B}_{4} \mathrm{C}$ in graphite matrix & \\
\hline Shutdown units $\left(2^{\text {nd }}\right.$ Shutdown $)$ & 7 & Pieces \\
\hline Small ball shutdown element diameter ( $2^{\text {nd }}$ shutdown) & 5 & $\mathrm{Mm}$ \\
\hline
\end{tabular}

Referring to the Government Decree No. 2, 2014, for the construction of new commercial and non-commercial nuclear reactors, some permits must be satisfied, such as site and construction permits, commissioning, operation and even decommissioning licenses. In addition, BATAN has completed Revision 0 of some important documents related to consultant management for construction, process and quality improvement of site licensing, preparation of bidding documents, etc. All of the documents have been distributed to BAPPENAS to support the RDE bluebook and the green book is then considered to assure the civil construction of RDE and non-safety related devices can handled by Indonesia's engineering companies.

b. National existing capabilities and strategies on nuclear fuel $R \& D s$ and fabrication.

BATAN has safely operated two kinds of fuel fabrication plants, namely, fuel 
element production installation (FEPI) to support RSG-GAS fuels and experimental fuel element installation (EFEI) to carry out R\&Ds on nuclear power fuels since 1989. Due to the policy of BATAN, the fuel plant for RSG-GAS reactor was handed over to the Ministry of State-Owned Company (BUMN) in 1997. BATAN had then to provide its RSG-GAS fuel need from the limited company, now called INUKI Limited Company. Due to the relevant laws, BATAN has then tasks to implement R\&Ds on designing, modelling and fabricating of nuclear fuels, as well as doing post irradiation examination (PIE) of a designed fuel in the RSG-GAS reactor core and others. To achieve the national goals as stated in RIPIN 2015-2035 regarding nuclear power industry and the support of RDE fuels in the future, BATAN and national stakeholders should define the strategy as well as a national road map to provide
HTGR/RDE fuels for RDE operation. Similar RDE with bigger power of 50 MWe can be deployed in the Eastern part of Indonesia $[5,7]$ and based on the Indonesia Nuclear Energy Outlook 2014-INEO [8], the existence of nuclear powers of small medium powers (25 MWe to 200/300 MWe) should already be available in that area in $2027 / 2028$ or even sooner due to the need of new and renewable-energy-generated electricity.

Referring to Figure 3, BATAN should lead, based on the applicable laws in the country, all nuclear-research activities to support the nuclear fuel plant development in Indonesia. To minimize the risk and guarantee public acceptance, the site candidate for the nuclear fuel plant may be better in Puspiptek Area Serpong where the RDE will be built. To begin the construction of the nuclear fuel plant, some strategies as seen in Figure 3 should be followed.

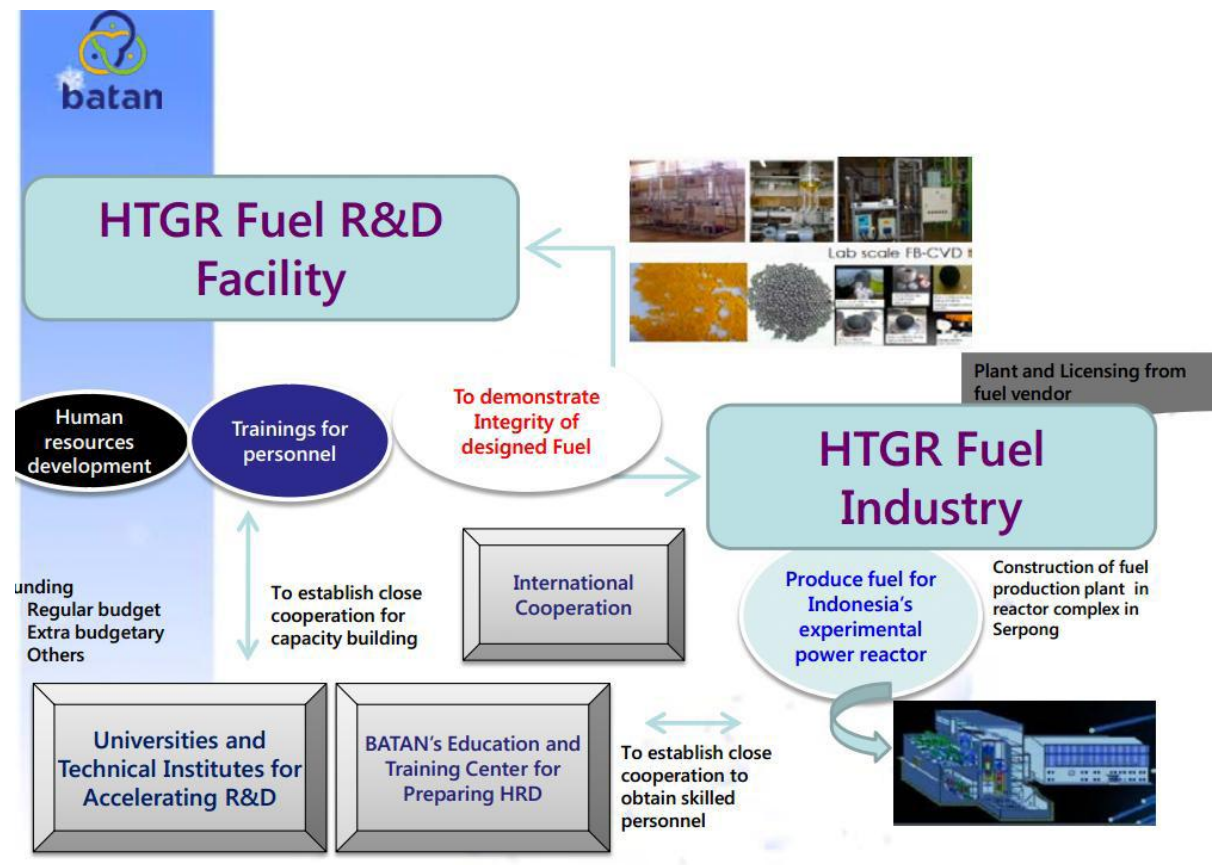

Figure 3. The Strategy to support HTGR fuel for RDE operation

BATAN should have HTGR fuel R\&D facility. As previously mentioned, BATAN has some R\&D facilities, for instance, hot cell for PIE and non-destructive test (NDT) devices for investigating broken fuels resulted from research activities. However, those all are old-style devices due to the 1980's fabrication and hence new 
facilites for nuclear fuel R\&Ds should be provided. In addition, nuclear skilled engineers are currently limited due to the policy of the Indonesia government to limit human resource recruitment in the country. To improve a national capacity building in nuclear field, the collaboration among BATAN, universities, related ministries and technical institutions should be soon enhanced. The collaboration with International Atomic Energy Agency (IAEA) and other foreign technical institutions, such as Japan Atomic Energy Agency (JAEA), Russian Atom Agency (Rosatom), Idaho Nuclear Laboratory (INL), Argonne National Laboratory (ANL), Oak Ridge National Laboratory (ORNL), etc. should be soon presented as well. Regarding the big capital needed for nuclear fuel plant construction, two ideas on financing can be taken into account. Firstly, as previously mentioned, the RDE program has met the national vision stated by Mr. President Joko Widodo (Self Reliance, Prosperity and Sovereignity) [3]. Based on the Government Decree No. 14 year 2015, the nuclear-based industry is a part of Master Plan of Indonesian Industry 2015-2035 and that should be supported by the government. To maximize local content for EPC, the RDE financing can be totally supported by all related state-owned enterprises, for example, the national electricity company (PLN), the national heavy industry company (BARATA), Rekin/RE, Wika, HK (coal/civil engineering companies) and others $[9,10]$. This will firstly make the country very beneficial since the EPC companies will have such a freedom to make all policies on RDE construction. Secondly, if the all related state-owned enterprises are not able to participate in supporting the RDE construction budgeting, G-to-G soft loans can be counted. If it is the case, the policy on RDE-EPC will then be taken over by a selected donor country. Since the donor country has its own money to support the project, it will make a lot of requests more for its beneficialness rather than for the national's, the actual owner of the RDE project.

\section{c. R\&Ds on HTGR fuels in the regions}

Research and developments (R\&Ds) on HTGR fuels are spread out all over the world, such as Germany and other European countries, Asia Pacific countries (China, Japan, Korea etc.), South Africa, and USA. For example, R\&Ds on HTGR fuels in the fields of coated particles, fiision product, integrity and corrosion have been implemented by Germany, France, USA, Japan, China and Sout Africa. Besides, R\&Ds on ultra-high burn-up and fabrication of the corresponding coated particles and strength have been carried out by the same countries previously mentioned. Lastly, the R\&Ds on safety features, $\mathrm{Ag}$ on $\mathrm{SiC}$ layer and process to coated-particle strength and burning $\mathrm{Pu}$ in pebble bed as well as the improvement of future HTGR fuel have been employed by few Europe countries and South Africa. In the following sub-section, the main R\&Ds on the improved HTGR coated fuels will be briefly described.

\section{The United States of America (USA)}

The R\&D of post irradiation examination (PIE) of HTGR fuels has been of one of the main research areas in the USA since 1990's or even before and the R\&D on the evolution for HTGR fuel particle design and its performance has been directed at fission products [6]. The PIE performance of TRISO-coated gas reactor particle fuel in Germany has been superior to that in the States, and a US fuel compact has a higher packing fraction of particles (up to $50 \%$ ) than German pebbles (10\%) and the US core design also uses a higher fuel power density than the German core designs [4]. For future HTGR fuels, very high temperature reactors (VHTRs) are designed to have coolant outlet temperatures up to $1000^{\circ} \mathrm{C}$ since those force the plant efficiency increase and the ability to the multi-use heat in the reactor core [2]. 
Referring to $[6,11,12]$, TRISOcoated particle fuel has been fabricated and tested around the world and a review of the fuel performance database indicates that high-quality low-defect TRISO fuel, which is the heart of the high-temperature gas-cooled reactor, can be accomplished if the following conditions are met, such as a) disciplined and controlled fabrication of the coated particles; b) selection of normal operation conditions result in very low failures; c) wellplanned series of irradiations that limit the burn-up and fluence acceleration to preclude artificial failures that would not be expected in the actual reactor application; d) selection of an accident envelope up to $1600^{\circ} \mathrm{C}$ will result in very low failures; e) well-planned accident safety testing that tests enough fuel, minimum 200,000 particles, to draw statistically significant conclusions.

From all HTGR research activities previously abridged, it is verified that there is a lot of R\&Ds on HTGR fuels in the USA since 1990's till to date. A large nuclear community in the States may assuredly perform HTGR-fuel research activities now and in the future. This, of course, implies that the manufacturers of HTGR fuels will have also very developed in the States.

\section{South Africa}

A pebble bed modular reactor (PBMR) had been a particular design of pebble bed reactor under development by South African company PBMR (Pty) Ltd since 1994. The project entails the construction of a demonstration power plant at Koeberg near Cape Town and a fuel plant at Pelindaba near Pretoria [13]. The PBMR is characterized by inherent safety features and can be used for industrial purposes [14]. The research on the detection of metallic silver on Chemical Vapour Deposited (CVD) grown silicon carbide and in PBMR supplied tri-structural isotropic (TRISO) coated particles with $500 \mu \mathrm{m}$ diameter zirconium oxide surrogate kernel have been investigated [15]. Furthermore, deposition temperature and gas inlet design were proved to be the only process parameters that influenced the coated particle crush strength [16]. Lastly, grain boundary stoichiometry, SiC grain size and shape, the presence of free silicon, nano-cracks, thermal decomposition, palladium attack, transmutation products, layer thinning and coated particle shape are assured to influence $\mathrm{Ag}$ transport in the coated particle [17]. In early 2010, the South Africa government announced the stop of funding for the development of the PBMR project because no customers or investors were found for it. However, the PBMR experts involved in the HTGR fuel research activities are still requested, at least, to give the assistance to review the RDE design development in Indonesia.

\section{Japan Atomic Energy Agency (JAEA)}

Japan had been one of the leader countries to deal with R\&Ds on HTGRs in 1980 s and in 1990s in the World [8]. Here are some significant R\&Ds on HTGR fuels in Japan. First, JAEA innovated new combinations of coating layers which were invented to prevent the corrosion of the SiC layer by fission products. Through the fabrication and irradiation experiments, the advanced coatings and the additional layers of $\mathrm{SiC}$ and $\mathrm{SiC}+\mathrm{PyC}$ trapped palladium effectively to prevent the corrosion of the SiC layer [4]. Second, JAEA has also developed zirconium carbide ( $\mathrm{ZrC}$ )-coated fuel particles in laboratory scale. They are assured to maintain their integrity at higher temperatures and burn-up conditions [18]. Third, Japan presented that VHTR is a principal candidate for the Generation IV reactor systems. In additon, for ZrC-TRISO coated fuel as an advanced fuel design, JAEA in collaboration with ORNL carried out R\&Ds for the fabrication, inspection and PIE's of that ZrC-TRISO coated fuel. Lastly, in order to investigate the potential of high temperature gas-cooled reactors (HTGRs) for transmutation of long-lived fission 
products (LLFPs), numerical simulation of four types of HTGRs was carried out. An efficient LLFP transmutation using the Clean Burn without MA (minor actinides) proved to achieve very high burn-ups and producing the transmutation [19].

Referring to Japan HTGR fuel manufacturer, Nuclear Fuel Industries (NFI), Ltd. is one of nuclear fuel producers, through its subsidiaries, develops, designs, and produces nuclear fuel for boiling-water reactors and pressurized-water reactors [20]. The company was founded in 1972 and is spread out in Japan even in Paris, France. The company also engages in $R \& D$ on nuclear reactors, such as fabricating reactor fuel components for light water, fast breeder, high temperature gas-cooled reactors (HTGR) and others. From all elucidation previously mentioned, all research activities on HTGR fuels in Japan have still indeed developed since Japan is one of the advanced countries to develop Gen-IV reactors, which are expected to be commercially operated in 2030s. Japan has indeed some professional HTGR fuel manufacturers, so that this can be appointed to support HTGR fuels for RDE operation in the future.

\section{Germany-France and others}

The coated particles for HTGR fuels were firstly invented by Roy Huddle in Harwell 1957 and more than half a million spherical fuel elements with high-enriched uranium (HEU) has been manufactured in Germany [4]. Many elements containing high-enriched uranium and thorium oxide fuels have been successfully tested in Material Testing Reactors (MTRs) and in Advanced Very High Temperature Reactor (AVR) under high temperatures. The development of spherical fuel elements for HTR-designs in Germany had been tremendously amazing and in 2002, that was specifically given to the development, production and characterization including kernel and coatings as well as to the irradiation and post-irradiation examination of the different coated particle systems [21]. In the framework of the French V/HTR fuel development and qualification program, the Commissariat a' l'Energie Atomique (CEA) and AREVA conducted R\&D projects dealing with the mastering of $\mathrm{UO}_{2}$ coated particle and fuel compact fabrication technology. An experimental manufacturing line for coated particles and a compacting line based on former CERCA compacting experience have been designed, constructed and operated since early 2005 at CEA Cadarache and CERCA Romans [22].

Until 2007, in Germany, early fuel development and testing were oriented towards the requirements of thorium high-temperature nuclear reactor (THTR) prototype for successor reactor designs, for process heat applications, etc. It proved to be that the coated particle should be strong, reliable, retentive, and affordable [23]. In the same year, the TRISO particle design of high temperature reactors fueled with plutonium (Pu) and/or minor actinides (MAs) was investigated by calculating the failure fraction of TRISO particles during irradiation. The results showed that the pebble-bed type high temperature reactor under consideration is a promising option for burning $\mathrm{Pu}$ and MAs [24]. The NUKEM design has demonstrated the best fission product release rate, particularly at high temperatures. Although the HTGR fuel designs have their own complexity, they have developments and economical aspects of the fabrication processes[25]. In 2013, the German High Temperature Reactor Fuel Development Program successfully developed, licensed and manufactured many thousands of spherical fuel elements that were used to power the experimental AVR reactor and the commercial THTR reactor [26]. Furthermore, fuel elements were manufactured in production scale facilities containing near defect-free $\mathrm{UO}_{2}$ TRISO coated particles and homogeneously 
distributed within a graphite matrix with very low levels of uranium contamination.

Regarding HTGR fuel manufacturers in Europe and from its company profile[27], Atomstroyexport (JSC ASE) is an engineering company of ROSATOM dealing with construction of nuclear power facilities abroad, and the company delivered new nuclear build projects in China (Tianwan 1,2) and India (Kudankulam-1) and has new reactors construction projects underway in China, India, Turkey and Bellarussia. NUKEM Technologies German company is a subsidiary of Atomstroyexport and has more than 50 years of extensive experience in the spheres of radioactive waste (RW) and SNF (spent nuclear fuel) management, decommissioning, as well providing engineering and consultancy services and the company is among pioneers in HTGR technology. In addition, Scientific \& Industrial Association (SIA) "LUCH", a Russian Company and founded in 1946, provides the nuclear industry with fuel elements and fuel assemblies for nuclear power propulsion vessels, and also develops fuel elements of new generation. NUKEM as Atomstroyexport and SIA are concluded as two of the best companies to support HTGR fuels for RDE operation.

\section{The Institute of Nuclear and New Energy Technology (INET) and China North Nuclear Fuel, People Republic of China (PRC).}

The first HTR-10 attained its first criticality at the end of 2000 and the fabrication of the first fuel for the HTR-10 started in February 2000 at the Institute of Nuclear Energy Technology (INET), Tsinghua University and up to September 2000 , more than 11,500 spherical fuel elements were successfully produced [28]. The coated particles are of major concern on manufacturing spherical fuel elements and the pressure signals in the coating furnace are obtained experimentally from the TRISO $\mathrm{UO}_{2}$-coated fuel particle fabrication process.
During the successive coating process of the buffer PyC, IPyC, SiC and OPyC layer, the pressure signals analysis is indeed an effective method to monitor the fluidized state on-line in the coating process at high temperature up to $1600^{\circ} \mathrm{C}$ [29].

The newly developed over-coater system and its corresponding parameters exhibited good stability and high efficiency in the preparation of over-coated particles and the 20-hour optimized carbonization improved the manufacturing efficiency. The spherical fuel elements and matrix graphite balls met the design specifications for HTR$\mathrm{PM}$ and the mean free uranium fraction of 5 consecutive batches was $87 \times 10^{-7}$ [30]. To fulfill the commercial development of HTGR, higher requirements for mass production of over-coated particles for fuel elements were investigated. The standardized experiment proved that the average stable yield is $93.94 \%$ and hence the over-coating equipment is easily operated and controlled, and satisfied the mass production [31]. Tristructural-isotropic (TRISO) particle has been successful in HTGR, but for future development, an improved design is required by preparing porous $\mathrm{SiC}$ layer called methods of high methyl tri-chlorosilane (MTS) concentration, high $\mathrm{Ar}$ concentration and hexa-methyl disilane (HMDS) investigated from scanning electron microscope (SEM), X-ray diffraction (XRD), Raman scattering and energy dispersive X-ray (EDX) analysis [32]. Referring to [3], after the first concrete was poured on December 9, 2012 at the Shidao Bay site in Rongcheng, Shandong Province, China. The construction of the reactor building for the world's first HTR-PM demonstration power plant was completed in June, 2015. Installation of the main equipment then began, and the power plant was planned to be connected to the grid at the end of 2017.

On July 17, 2017, the world's first production line for HTGR fuel elements has started mass production at China North 
Nuclear Fuel (CNNF), headquartered in Baotou in Northern China's Inner Mongolia Autonomous Region [33]. The 200,000 spherical fuel elements have been developed, marking a transition from a test production line to an industrial one. China has cemented its leading position as a manufacturer of HTGR fuel elements and with a designed capacity of 300,000 spherical fuel elements per year, the production line will provide fuels for the demonstration of HTGR plant built at Shidaowan, near Rongcheng city in Shandong Province. Indeed, China is one of the potential HTGR fuel vendors to be respected to support RDE operation.

\section{d. The Strategy to support HTGR fuels for RDE operation.}

To support HTGR fuels for RDE operation, the road map of HTGR fuel plant development is proposed as seen in Figure 4. The road map consists of three main activities to support the construction of HTGR fuel plant in Indonesia, namely, a) HTGR fuel R\&D programs for national capacity building; b) HTGR fuel industry program; and c) HTGR fuel loading for RDE operation

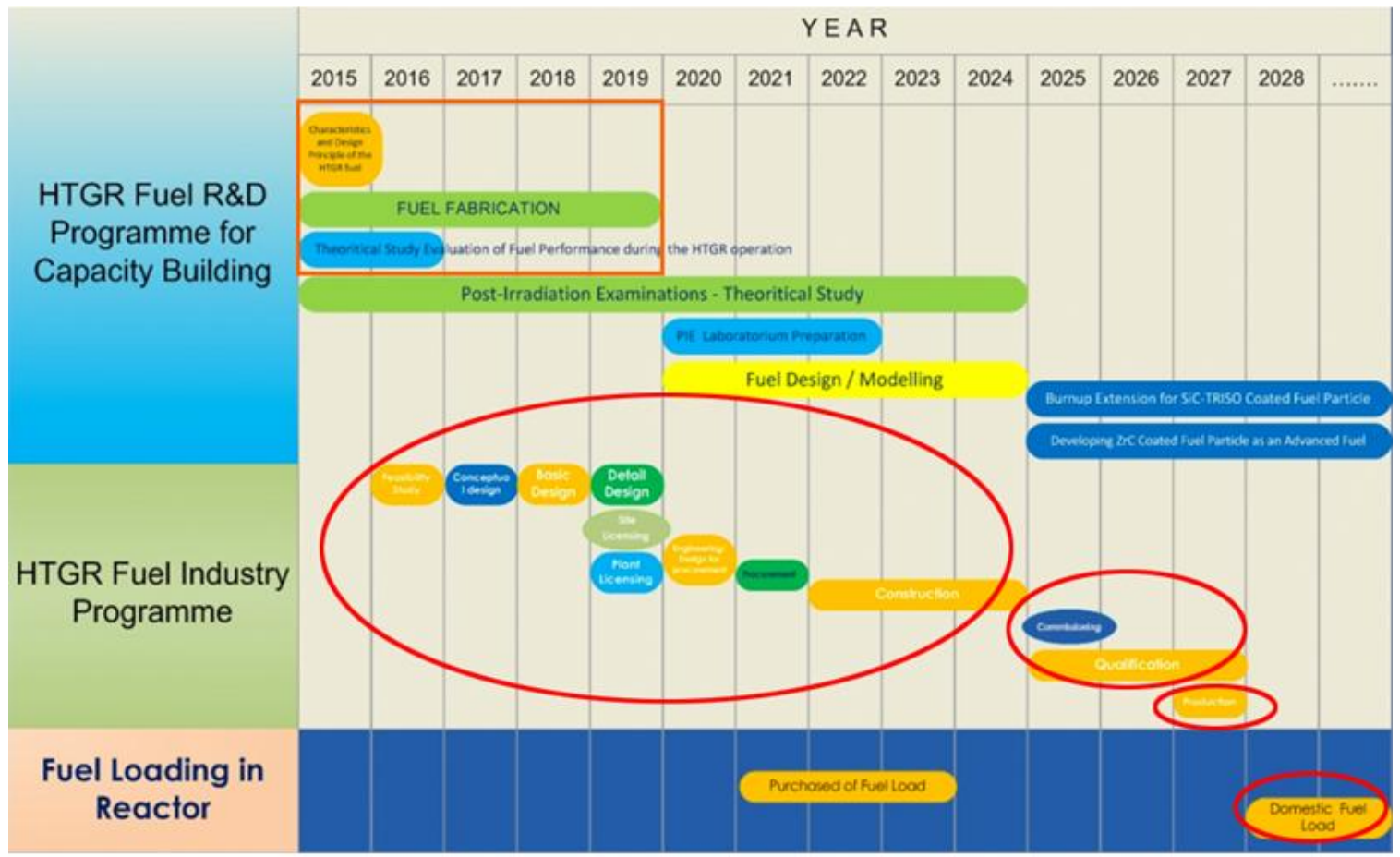

Slide Courtesy of Ridwan

Figure 4. Road map of HTGR fuel plant development in Indonesia.

HTGR fuel R\&D program for national capacity building: From the figure, during the years of 2015-2024, BATAN and national stakeholders, mainly universities and insitutions, related ministries and stateowned enterprises should do R\&Ds on HTGR fuels which are coordinated by the Ministry of Research, Technology and Higher Education. Those HTGR fuel R\&Ds should be also supported by BAPPENAS. The HTGR fuel research activities should deal with topics of HTGR fuel fabrication and comprehensive investigation on research fuels product. The latter is needed to ensure the produced prototype of HTGR fuels with good quality. Further, the more comprehensive research activities are carried out using PIEs, the more confident level of Indonesia's experts will have. Therefore, the latter research activities should be implemented till 2024, while the preparation for a new PIE facility should 
commence from 2020 to 2022. To support all researches previously mentioned, the research topic on HTGR fuel modeling should also be taken into account. As also seen in the Figure, when the HTGR fuel plant is completed at the end of 2024, R\&Ds on SiC coating particle and advanced HTGR fuel should then be prioritized. For all researches previously mentioned, to enhance and broaden the national capability on HTGR fuel production, collaboration not only with local institutions, but also with foreign institutions should be employed. One of the advantages which can be earned from these collaborated activities is to convince that nuclear based-industry research activities are belonged not only to BATAN but also to all national industry communities. Finally, as an outcome of all research activities previously stated and instigated, there will be a siginificant additional number of experts dealing with nuclear fields, especially in HTGR fuels.

HTGR fuel industry program: based on the scenarios depicted in Figure 4 , to construct the HTGR fuel plant, the feasibility study and the conceptual design of the HTGR fuel plant should be respectively completed in several coming years. The basic design dealing with all system specifications is expected to be instigated, hence the total budget needed for the HTGR fuel plant should already be accurately estimated. At that time, by using the documents previously mentioned, BATAN is able to apply site licensing to BAPETEN. After the EPC contract of the HTGR fuel plant completed, the project management and the main contractor for the HTGR fuel plant construction will be much busier at this time because they should commence to develop detail design needed for site licensing application. To support local content during the construction of the fuel plant, from the beginning, all systems and devices, whether or not related to nuclear islands, should already be clearly delineated. It is assured that all not-safety- related (industry standard) systems and devices can be guaranteed to be procured or even fabricated in Indonesia. However, all-nuclear-island systems and equipments are still to be fabricated in the vendor country.

From BATAN's experience in the past, i.e. the contruction of fuel element production installation in Serpong, the plant construction of the HTGR fuel plant will take 3-4 years. The commissioning of the plant will commence in 2025 and although this is the second time for the country to build the fuel plant, this is totally different compared to that constructed in Serpong in 1980s. It is noted that the HTGR fuel plant is more complicated than the previous one in Serpong. The qualification of the HTGR fuel plant should be lengthily tested and investigated in the period of 2025-2027. This is to assure that the new produced HTGR fuels meet with all the international manufacturing specifications. Finally, in 2028, the Indonesia HTGR fuel plant will be able to produce the internationallystandardized HTGR fuels for RDE daily operation.

HTGR fuel loading for RDE operation: Based on the scenario, the RDE will be operated commencing from 2022/2023 and all fuels needed for RDE operation in the years of 2023-2025 will be inclusive in the RDE EPC contract. From 2026-2027, the newly-produced HTGR fuels previously mentioned in section b) are needed to deeply investigate the quality of the produced HTGR fuels from the new HTGR fuel plant. Finally, in 2028, the Indonesia HTGR fuel plant will be able to provide all HTGR fuels for RDE daily operation.

\section{CONCLUSIONS}

The RDE development has become a progressive national program and can be preserved to strengthen international collaboration and hence to always be well 
informed with the world latest nuclear technology. The RDE will be a very good experience for the country to gain national capabilities in nuclear fields.

Since the RDE project will be partially financed by national budget, the existence of the project will open opportunities for local industries to actively participate in the RDE construction, especially in civil construction as well as in non-safety related devices. To reinforce the RDE fuel availability for its daily operation, two scenarios should be soon developed and implemented. The former scenario should provide HTGR fuels inclusive in the RDE-EPC contract for the first five year of RDE operation. The latter scenario should take into account the possibility to construct the RDE fuel production plant in the country. Some vendor countries, such as Japan, USA, Germany/Russia and China or combination of the two vendor countries can be indeed nominated to be the best HTGR fuel producer to support RDE daily operation in the future.

\section{ACKNOWLEDGEMENT}

The first author acknowledges the Chairman of BATAN who has assigned him as the chief of the RDE project management organization to establish all activities and hence the RDE will be operated safely and meets with national and international standards. The authors also thank the committee of guidance for researcher in PTKRN-BATAN to review and finally develop this paper qualified. Last but not least, the authors are indeed very grateful to staff of Division of Reactor Safety Technology and hence enabling them to develop this paper being wishfully worthwhile for nuclear community in Indonesia.

\section{REFERENCES}

[1] BATAN, "Studi Kelayakan Reaktor Daya Eksperimental (RDE)", Halaman I, Jakarta, 2016.

[2] T. Abram and S. Ion, "Generation-IV Nuclear Power: A Review of The State of The Science," Energy Policy vol. 36, pp. 4323-4330, 2008.

[3] Z. Zang, Y. Dong, F. Li, Z. Zhang, H. Wang, $X$. Huang, et al, "The Shandong Shidao Bay 200 MWe High Temperature Gas Cooled Reactor Pebble-Bed Module (HTR-PM) Demonstration Power Plant: An Engineering and Technological Innovation", Journal of Engineering, vol.2, Page 1-2, 2016.

[4] X. W. Zhou and C. H. Tang, "Current Status and Future Development of Coated Fuel Particles For High Temperature Gas-Cooled Reactors," Progress in Nuclear Energy,vol. 53, pp. 1-2, 2011.

[5] T. Taryo, Rokhmadi, G.R. Sunaryo and S. Bakhri, "The On-Going Progress of Indonesia's Experimental Power Reactor $10 \mathrm{MW}$ and Its National Research Activities", Presented in The National Seminar on Nuclear Energy Technology, October 2017,Makassar,

[6] J. Kinsey, "Summary of AGR Fuel Program", Technical Meeting on The Safety of High Temperature Gas Cooled Reactors In Light of The Fukushima Daiichi Accident, April 2014, IAEA Headquarters Vienna, Austria.

[7] T. Taryo, "The Current Status of Indonesia Experimental Power Reactor 10 MW (RDE-10)", Proceeding of The National Seminar of Nuclear Energy, pp. 961-968, 2016. 
[8] BATAN, "Indonesia Nuclear Energy Outlook 2014", 2014.

[9] Secretariat Cabinet, "The Presidential Instruction No. 2 Year 2009 Regarding The Utilization of Domestic Products for Government Procurement of Good Services," 2009.

[10] Secretariat Cabinet, "Presidential Decree No. 54 Year 2010 Regarding Government Procurement of Good Services," 2010.

[11] J. A. Phillips, S. G. Nagley, and E. L. Shaber, "Fabrication of Uranium OxyCarbide Kernels and Compacts for HTR Fuel", Nuclear Engineering And Design, vol. 251, pp.261-281, 2012.

[12] D. A. Petti, P. A. Demkowicz, J. T. Maki, and R. R. Hobbins, "TRISO Coated Nuclear Fuel Performance", Idaho, USA, 2015.

[13] S. Thomas, "PBMR: Hot Or Not?," Nuclear Engineering International, Archived From The Original On June 2011.

[14] PBMR Ltd., "Process Heat Applications," Archived from The Original on February 2012.

[15] D. E. Roberts, A. Du Plessis, J. Steyn, L. R. Botha, C. A. Strydom, and I. J. Van Rooyen, "Femtosecond Laser Induced Breakdown Spectroscopy of Silver Within Surrogate High Temperature Gas Reactor Fuel Coated Particles", Spectrochimica Acta Part B vol. 65, p. 918, 2010.

[16] R. D. Cromarty, G .T. Van Rooyen, and J. P. R. De Villiers, "Crush Strength of Silicon Carbide Coated TRISO Particles: Influence of Test Method and Process Variables," Journal Of Nuclear Materials vol. 445, p. 30, 2014.

[17] I. J. Van Rooyen, M. L. DunzikGougar, and P. M. Van Rooyen, "Silver (Ag) Transport Mechanisms In TRISO Coated Particles: A Critical
Review," Nuclear Engineering and Design, vol.271, p. 180, 2014.

[18] S. Ueta, J. Aihara, K. Sawa, A. Yasuda, M. Honda, and N. Furihata, "Development of High Temperature Gas-Cooled Reactor (HTGR) Fuel In Japan", Progress In Nuclear Energy, vol. 53, p. 788, 2011.

[19] K. Kora, H. Nakaya, H. Matsuura, M. Goto, S. Nakagawa, and S. Shimakawa, "A Study on Transmutation of LLFPS Using Various Types of HTGRs," Nuclear Engineering and Design, vol. 300, p. 330, 2016.

[20] www.Nfi.Co.Jp/E/Product/Prod3.Html, Dated On 13 September 2017.

[21] H. Nabielek, G. Kaiser, H. Huschka, $H$. Ragoss, M. Wimmers, and W. Theymann, "Fuel for Pebble Bed HTRs," Nuclear Engineering Design, vol. 78, 155-166, 1984.

[22] F. Charollais, S. Fonquernie, C. Perrais, M. Perez, O. Dugne, F. Cellier, G. Harbonnier, and M-P. Vitali, "CEA and AREVA R\&D on HTR Fuel Fabrication and Presentation of The CAPRI Experimental Manufacturing Line," Nuclear Engineering and Design, vol. 236, pp. 534-542, 2006.

[23] J. Jonnet, J. L. Kloosterman, and B. Boer, "Performance of TRISO Particles Fueled win A PBMR-400 Core Design," Nuclear Engineering and Design, vol. 240, p. 1320, 2010.

[24] U. Rohde, S. Baier, S. Duerigen, E. Fridman, S. Kliem, and B. Merk, "Development and Verification Of The Coupled 3D Neutron Kinetics/Thermal-Hydraulics Code DYN3D-HTR for The Simulation of Transients In Block-Type HTGR," Nuclear Engineering and Design, vol. 251, p. 412, 2012.

[25] M. J. Kania, H. Nabielek, K. Verfondern, and $\mathrm{H}$-J. Allelein, "Testing of HTR $\mathrm{UO}_{2}$ TRISO Fuels In AVR and In Material Test Reactors," Journal of 
Nuclear Materials, vol. 441, p. 545, 2013.

[26] G. Brähler, M. Hartung, J. Fachinger, K-H. Grosse, and R. Seemann, "Improvements in The Fabrication of HTR Fuel Elements," Nuclear Engineering and Design, vol. 251, p. 239, 2012.

[27] www.atomstroyexport.Ru/Wps/Wcm, 13 September 2017

[28] C. Tang, Y. Tang, J. Zhu, Y. Zou, J. $\mathrm{Li}$, and $\mathrm{X}$. Ni, "Design And Manufacture of The Fuel Element for The 10 MW High Temperature GasCooled Reactor," Nuclear Engineering and Design, vol. 218, p. 91, 2002.

[29] M. Liu, Y. Shao, and B. Liu, "Pressure Analysis In The Fabrication Process of TRISO $\mathrm{UO}_{2}$-Coated Fuel Particle," Nuclear Engineering and Design, vol. 250, p. 277, 2012.
[30] X. Zhou, Z. Lu, J. Zhang, B. Liu, Y. Zou, C. Tang, and Y. Tang, "Preparation of Spherical Fuel Elements For HTR-PM in INET," Nuclear Engineering and Design, vol. 203, p. 456, 2013.

[31] R. Liu, M. Liu, J. Chang, Y. Shao, and B. Liu, "An Improved Design of TRISO Particle with Porous SiC Inner Layer By Fluidized Bed-Chemical Vapor Deposition," Journal of Nuclear Materials, vol. 467, p. 917, 2015.

[32] X. W. Zhou, Z. M. Lu, J. Zhang, Y. P. Tang, and Y. W. Zou, "Research on The Overcoating Process In The Manufacture of Spherical Fuel Elements for HTGR", Nuclear Engineering and Design, vol. 271, p. 154, 2014.

[33] www.Nuclear-World-Exhibition.com and Www.Bloomberg.com, dated on 14 September, 2017. 